Research Article

\title{
Intralesional Bleomycin for the Treatment of Resistant Palmoplantar and Periungual Warts
}

\author{
Suchana Marahatta ${ }^{(D)}$, Dhan Keshar Khadka, Sudha Agrawal, and Arpana Rijal \\ Department of Dermatology \& Venereology, B. P. Koirala Institute of Health Sciences, Dharan, Nepal \\ Correspondence should be addressed to Suchana Marahatta; dermasuchana@gmail.com
}

Received 20 May 2021; Revised 31 August 2021; Accepted 14 September 2021; Published 18 October 2021

Academic Editor: Craig G. Burkhart

Copyright ( $\odot 2021$ Suchana Marahatta et al. This is an open access article distributed under the Creative Commons Attribution License, which permits unrestricted use, distribution, and reproduction in any medium, provided the original work is properly cited.

\begin{abstract}
Introduction. Periungual, palmar, and plantar warts are difficult to treat with poor treatment response. Intralesional (IL) bleomycin has shown promising results for their treatment in a few reports. However, we need further evidence before opting it for treating difficult sites and resistant warts. Hence, we conducted this study to assess the efficacy and safety of IL bleomycin for the treatment of resistant palmoplantar and periungual warts. Methods. In this retrospective study, we included all patients who were given IL bleomycin for warts over a year. Maximum three sittings of bleomycin $(1 \mathrm{mg} / \mathrm{ml})$ were given monthly, and they were followed up for 3 months after the procedure. The response was categorized as complete, near-complete, significant, moderate, mild, and no clearance for $100 \%, 75-99 \%, 50-74 \%, 25-49 \%, 1-25 \%$, and $0 \%$ clearance, respectively. Results. Out of 29 patients, follow-up details were available only in 19 patients (53 warts). The mean duration was $2.5 \pm 1.47$ years. The number of past interventions ranged from 2-4. Wart clearance after the first intervention was complete in $36.84 \%$, near-complete in $26.31 \%$, significant in $26.31 \%$, and moderate in $10.53 \%$. Wart clearance after the last intervention was complete in $89.47 \%$ and near-complete in $10.52 \%$ of patients. However, during 3 months of follow-up after the last injection, $15.78 \%$ had a recurrence. None of them had severe local and systemic side effects. Conclusions. IL bleomycin could be a better treatment option for the treatment of resistant and difficult warts. However, we observed a higher recurrence rate even in a shorter follow-up. Hence, we need further studies with larger samples.
\end{abstract}

\section{Introduction}

Warts are a widespread cutaneous infection which affects trauma-prone sites such as periungual areas, palms, and soles [1]. It could be more prevalent among Nepalese as most of them are farmers, walk barefoot, and share community bathing and common water sources. Although spontaneous clearance is possible, many opt for treatment for cosmetic concerns, social stigma, pain, risk of malignancies, etc. [2]. Bleomycin is an antitumor and antiviral agent commonly used for the treatment of squamous cell carcinoma [3].

Available studies have recommended cryotherapy and salicylic acid (SA) as first-line therapies for warts [4]. However, cryotherapy may not be easily available even in developing countries. SA needs a longer treatment, and the patient's compliance cannot be confirmed [1]. Moreover, a significant numbers of periungual (72\%) and palmoplantar (31\%) warts are resistant to common treatments. Thus, we need to be wiser while choosing the most appropriate therapeutic modalities [5].

Currently, there is limited evidence of intralesional (IL) bleomycin for treating recalcitrant warts. Some reports have shown positive results with cure rates ranging from $14 \%$ $99 \%[6,7]$. Hence, we conducted this study to assess the efficacy and safety of IL bleomycin for the treatment of palmoplantar and periungual warts.

\section{Methods}

In this retrospective case series, we extracted data from the eligible patient's record maintained in the operation theater (OT) of the dermatology department of BPKIHS from March 2017 to February 2018. We included patients of age $\geq 18$ years with recalcitrant and difficult site warts, who had never received IL bleomycin in past. However, whose followup details were not available till three months after the last 
intervention and with immunocompromised status were excluded from the study. We extracted relevant patients' particulars such as age, gender, occupation, and education. We also noted clinical details such as disease duration, progression, and the name and the number of past interventions. Photographic records were maintained during all visits. Similarly, the details of examination findings such as the number, site, size of warts, and side effects were recorded at baseline as well as at each follow-up visit to assess the size reduction and efficacy of the treatment.

\subsection{Case Definitions.}

Resistant warts: they were defined as warts that have failed treatment twice in the past

Difficult site warts: they were defined as periungual, palmar, and plantar warts

2.2. Injection Technique. Bleomycin for injection was obtained in vials containing $15 \mathrm{mg}(15 \mathrm{U})$ of powder. It was first reconstituted with $5 \mathrm{ml}$ sterile water for injection to prepare the stock solution, which was stored at $4-8^{\circ} \mathrm{C}$ for a maximum of 60 days. Then, one part of bleomycin stock solution and two parts of $2 \%$ lignocaine were taken in a $26 \mathrm{G}$ insulin syringe to make a final concentration of $1 \mathrm{U} / \mathrm{mL}(=1 \mathrm{mg} / \mathrm{mL})$ just before injection. Each wart and the adjacent skin were cleaned with isopropyl alcohol before injection. The injection was given at the base of each wart until the lesion was blanched. The amount of injection was decided depending on the size of the warts: warts up to $5 \mathrm{~mm}, 10 \mathrm{~mm}$, and more than $10 \mathrm{~mm}$ received $0.2 \mathrm{~mL}, 0.5 \mathrm{~mL}$, and $1.0 \mathrm{~mL}$ of bleomycin, respectively. The total volume injected at one treatment session was limited to $2 \mathrm{~mL}$, and the injection into a single wart was limited to $1 \mathrm{~mL}$. Similarly, a maximum of 5 warts were treated in a session to avoid systemic side effects $[8,9]$. The treated warts were given a specific number to avoid confusion during follow-up.

2.3. Assessment and Follow-Up. Patients were reevaluated at 4 weeks' interval. Any remaining keratotic tissues were pared off with a scalpel blade. If warts persisted or recurred after injection, the treatment was repeated using the same concentration and technique. However, it was not repeated for more than two follow-up sessions. The side effects of the injection such as pain, edema, oozing, crusting, and Raynaud's phenomenon were recorded in each follow-up visit. Patients were followed up to 3 months of the last intervention. The response was categorized as complete clearance, nearcomplete clearance, significant clearance, moderate clearance, mild clearance, and no clearance for 100\%, 75-99\%, 50-74\%, $25-49 \%, 1-25 \%$, and $0 \%$ clearance, respectively.

\section{Results}

Out of 29 patients (94 warts) subjected to IL bleomycin injection, only 19 subjects (=53 warts) fulfilled the inclusion criteria. The mean age of the patients was $27.95 \pm /-11.72$ years. The mean duration of the wart was $2.5 \pm /-1.47$ years, and the mean number of warts was $2.79 \pm /-1.81$ (range: $1-6$ ). The number of past interventions ranged from 2-5. Sites of the warts were plantar $=10$, periungual $=7$, palmar $=1$, and palmoplantar $=1$ (Table 1$)$.

Wart clearance after the first intervention was complete in $7(36.84 \%)$, near-complete in $5(26.31 \%)$, significant in 5 (26.31\%), and moderate in $2(10.53 \%)$. Wart clearance after the last intervention was complete in 17 (89.47\%) and nearcomplete in $2(10.52 \%)$ patients (Figures 1-3). However, during the 3 months' follow-up after the last injection, 3 patients, i.e., 3/19 (15.78\%), had a recurrence (Figure 4). None of the patients had severe local and systemic side effects. Local pain, edema, and crusting were the most common side effects and were seen in almost all patients. Duration of pain was 3 days (7 patients), 2 days ( 4 patients), 1 day ( 5 patients), and 7 days ( 2 patients). In three patients, we noticed temporary skin pigmentation. However, severe side effects were not seen in any of them.

\section{Discussion}

The mean duration of wart was $2.5 \pm 1.47$ years, and the mean number was $2.79 \pm 1.81$ (range: $1-6$ ). The number of past interventions ranged from 2-4. In our study, IL bleomycin $(1 \mathrm{U} / \mathrm{ml})$ had $36.84 \%$ and $89.47 \%$ complete clearance rates after the 1 st and 3rd interventions, respectively, for the treatment of difficult site recalcitrant warts. We found $15.78 \%$ recurrence rate within 3 months of the last intervention. However, it was devoid of serious adverse effects with transient pain up to 3 days being the most common $(84.21 \%)$ adverse effects.

Warts are the most common cutaneous viral infection. Although self-clearance is possible in many lesions, many patients want its treatment [2]. To date, there is no specific guideline for treating nongenital warts. However, a metaanalysis and pooled analysis of RCT found the highest (58\%) cure rate of the wart with cryotherapy and SA combination treatment, which were followed by aggressive cryotherapy (54\%), cryotherapy (49\%), SA (52\%), and placebo (23\%). Available evidence supports and recommends only aggressive cryotherapy and SA strongly for the treatment of warts, while higher-quality evidence is lacking to support other modalities. Treatment of recalcitrant warts at difficult sites is even more challenging. Almost $72 \%$ of periungual warts and $31 \%$ of palmoplantar warts are resistant to commonly used therapeutic modalities [5]. Moreover, cryotherapy may not be available in all centers in the developing world, and compliance cannot be insured in SA.

Bleomycin is an antitumor agent with the antiviral property. A few countable researchers had tried IL bleomycin for treating warts with inconsistent efficacy ranging from 14-99\%. However, some recent reports have shown very promising results $[7,8,10-12]$. We had almost comparable complete clearance rate with the previous reports, ranging from $69.3 \%$ to $96.47 \%$ (Table 2) $[8,9,11-16]$. A little higher clearance was obtained by Dhar et al. [8] (CC: 94.9\%), including all cutaneous warts without prior treatment. Soni et al. (CC: $96.47 \%$ ) had 
TABLE 1: Baseline characteristics and treatment outcome of the warts.

\begin{tabular}{|c|c|c|c|c|c|c|c|c|}
\hline $\begin{array}{l}\text { S. } \\
\text { no. }\end{array}$ & $\begin{array}{c}\text { Age (in } \\
\text { years)/gender }\end{array}$ & Site of wart & $\begin{array}{c}\text { Number of past } \\
\text { interventions }\end{array}$ & $\begin{array}{c}\text { No. of } \\
\text { warts }\end{array}$ & Past procedure & $\begin{array}{c}\text { Size of the largest } \\
\text { wart }(\mathrm{mm})\end{array}$ & $\begin{array}{c}\text { Treatment } \\
\text { sessions }\end{array}$ & Outcome \\
\hline 2 & $37 / \mathrm{M}$ & Periungual & 2 & 2 & CO2 LASER & $10 \times 5$ & 2 & CC \\
\hline 3 & $56 / \mathrm{F}$ & Periungual & 3 & 3 & EC and excision & $10 \times 5$ & 1 & $\mathrm{CC}$ \\
\hline 4 & $19 / \mathrm{F}$ & Plantar & 2 & 4 & $\mathrm{EC}$ & $6 \times 6$ & 2 & $\mathrm{CC}$ \\
\hline 5 & $16 / \mathrm{M}$ & Plantar & 2 & 1 & Excision & $15 \times 15$ & 1 & $\mathrm{CC}$ \\
\hline 6 & $28 / \mathrm{M}$ & Periungual & 2 & 1 & EC & $10 \times 6$ & 2 & $\mathrm{CC}$ \\
\hline 7 & $18 / \mathrm{F}$ & Periungual & 3 & 2 & EC & $15 \times 5$ & 2 & $\mathrm{CC}$ \\
\hline 8 & $18 / \mathrm{F}$ & Plantar & 4 & 5 & Chemical cautery & $25 \times 15$ & 3 & $\mathrm{R}$ \\
\hline 9 & $24 / \mathrm{M}$ & Plantar & 2 & 3 & $\mathrm{EC}$ & $6 \times 6$ & 2 & CC \\
\hline 10 & $19 / \mathrm{F}$ & Plantar & 2 & 5 & EC & $3 \times 5$ & 1 & $\mathrm{CC}$ \\
\hline 11 & $37 / \mathrm{M}$ & Periungual & 2 & 1 & CO2 LASER & $10 \times 5$ & 2 & $\mathrm{CC}$ \\
\hline 12 & $19 / \mathrm{M}$ & Plantar & 5 & 6 & EC & $25 \times 20$ & 2 & CC \\
\hline 13 & $19 / \mathrm{F}$ & Periungual & 2 & 1 & EC & $9 \times 4$ & 1 & $\mathrm{CC}$ \\
\hline 14 & $34 / \mathrm{F}$ & Plantar & 3 & 6 & Excision & $12 \times 10$ & 1 & CC \\
\hline 15 & $21 / \mathrm{F}$ & Palmoplantar & 3 & 4 & Excision & 10.8 & 2 & $\mathrm{R}$ \\
\hline 16 & $35 / F$ & Plantar & 2 & 1 & $\begin{array}{c}\text { Chemical cautery } \\
\text { and EC }\end{array}$ & $12 \times 11$ & 3 & $\mathrm{NC}$ \\
\hline 17 & $25 / \mathrm{M}$ & Palmar & 3 & 1 & EC & $10 \times 9$ & 3 & $\mathrm{NC}$ \\
\hline 18 & $26 / \mathrm{M}$ & Plantar & 2 & 2 & $\mathrm{EC}$ & $12 \times 10$ & 1 & $\mathrm{CC}$ \\
\hline 19 & $27 / M$ & Plantar & 2 & 4 & Excision & $10 \times 5$ & 2 & $\mathrm{R}$ \\
\hline 20 & $54 / \mathrm{F}$ & Periungual & 3 & 1 & EC & $25 \times 15$ & 1 & CC \\
\hline
\end{tabular}

EC: electrocautery, CC: complete clearance; NC: near-complete clearance; R: recurrence.

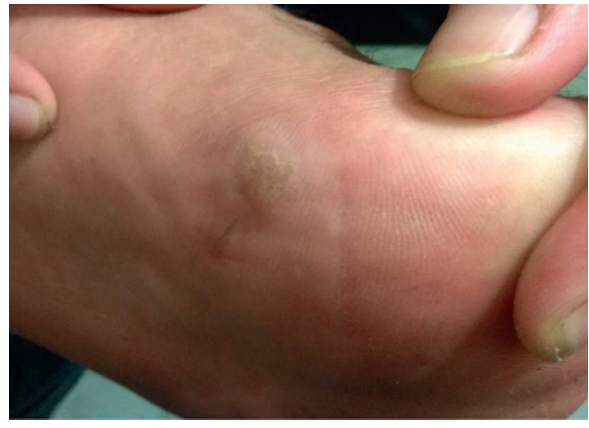

(a)

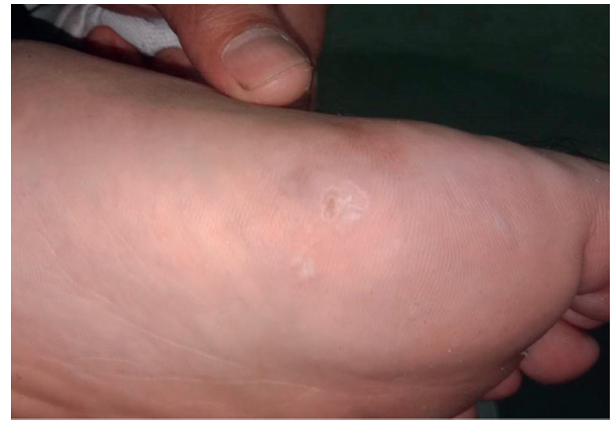

(b)

Figure 1: Plantar wart during baseline (a) and after one treatment session (b).

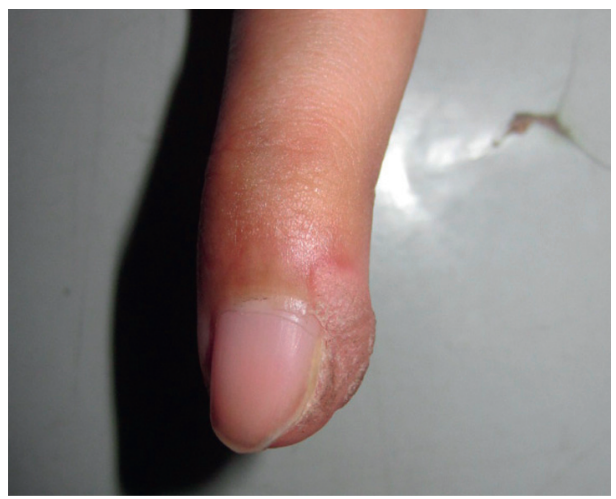

(a)

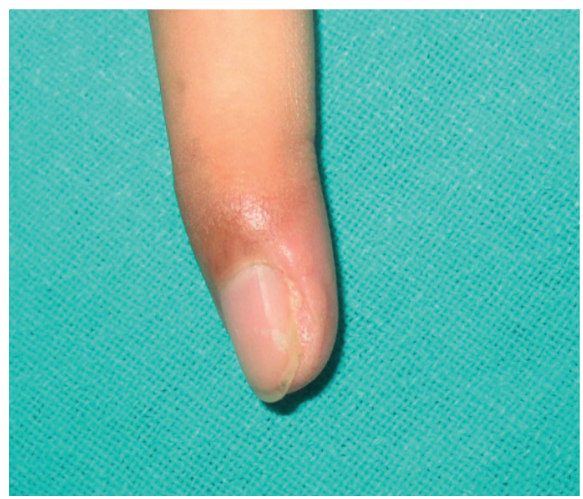

(b)

Figure 2: Periungual wart during baseline (a) and after two treatment sessions (b). 


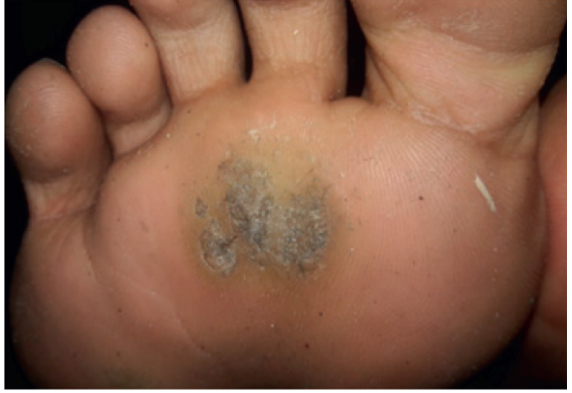

(a)

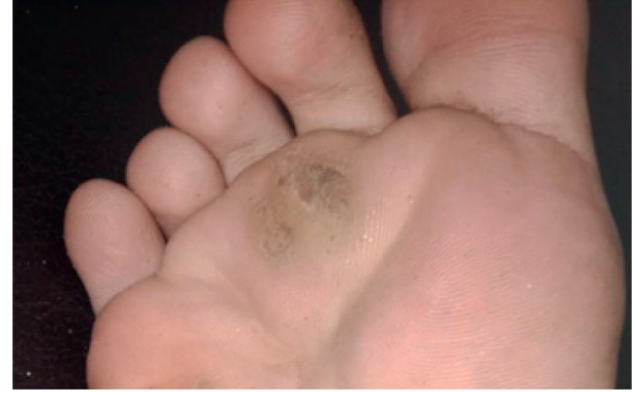

(b)

Figure 3: Plantar wart at baseline (a) and moderate clearance (b) after two treatment sessions.

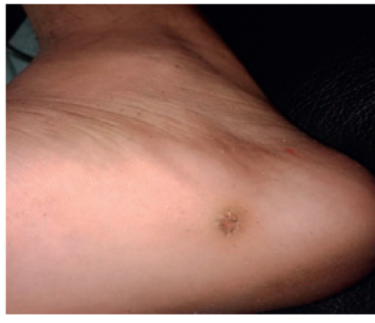

(a)

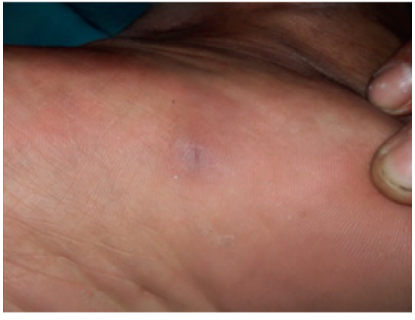

(b)

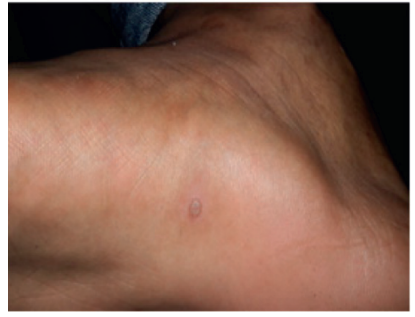

(c)

Figure 4: Plantar wart at baseline (a), complete clearance after one treatment session (b), and recurrence at 3 months posttreatment followup (c).

TABLE 2: Literature review (from the year 2005 to August 2020).

\begin{tabular}{|c|c|c|c|}
\hline Authors & Intervention (study design) & Results & $\begin{array}{c}\text { Follow-up } \\
\text { duration }\end{array}$ \\
\hline Our study & IL bleomycin only (retrospective case series) & CC (89.47\%), RR (15.78\%) & 3 months \\
\hline Barkat et al. [12] & IL bleomycin vs. placebo (RCT) & $\begin{array}{l}\text { Bleomycin }=\text { dermoscopic clearance }(69.3 \%) \\
\text { CC }(88.5 \%), \text { CC of placebo }(0 \%)\end{array}$ & 3 months \\
\hline Pasquali et al. [13] & $\begin{array}{l}\text { IL bleomycin + electropolation vs. IL bleomycin only } \\
\text { (prospective case series) }\end{array}$ & $\begin{array}{c}\text { CC of IL bleomycin + electroporation }(78 \%) \\
\text { bleomycin only }(16 \%)\end{array}$ & 3 months \\
\hline Dhar et al. [8] & IL bleomycin & $\begin{array}{c}\text { CC of bleomycin ( } 94.9 \%) \text {; cryotherapy }(76.5 \%) ; \\
\text { RR }(13 \%)\end{array}$ & 8 weeks \\
\hline $\begin{array}{l}\text { Adalatkhah } \\
\text { et al. [14] }\end{array}$ & IL bleomycin vs. cryotherapy (RCT) & CC of bleomycin (86\%), cryotherapy $(68 \%)$ & 6 weeks \\
\hline $\begin{array}{l}\text { Al-Naggar } \\
\text { et al. [15] }\end{array}$ & $\begin{array}{l}\text { IL bleomycin vs. microneedling assisted topical } \\
\text { bleomycin spray (RCT) }\end{array}$ & $\begin{array}{l}\text { CC of IL bleomycin (70\%), CC of } \\
\text { microneedling-assisted topical spray (83.3\%) }\end{array}$ & 6 months \\
\hline Soni et al. [9] & IL bleomycin vs. placebo (RCT) & $\begin{array}{c}\text { CC of IL bleomycin }(96.47 \%) \text { vs. placebo } \\
(11.11 \%)\end{array}$ & 12 months \\
\hline $\begin{array}{l}\text { Salk and } \\
\text { Douglas [16] }\end{array}$ & IL bleomycin only (prospective study) & CC (87\%), RR (19.35\%) & 6 months \\
\hline $\begin{array}{l}\text { Alghamdi and } \\
\text { Khurram [17] }\end{array}$ & $\begin{array}{l}\text { Translesional multipuncture technique with } 0.1 \mathrm{U} / \mathrm{ml} \\
\text { concentration for periungual warts (prospective study) }\end{array}$ & CC (86.6\%), RR (13.33\%) & 6 months \\
\hline $\begin{array}{l}\text { Alghamdi and } \\
\text { Khurram [11] }\end{array}$ & $\begin{array}{l}\text { Translesional multipuncture technique with } 0.1 \mathrm{U} / \mathrm{ml} \\
\text { concentration for plantar warts (prospective study) }\end{array}$ & CC (74\%), no response (13\%), RR: $9.5 \%$ & 3 months \\
\hline $\begin{array}{l}\text { Aziz-Jalali } \\
\text { et al. [5] }\end{array}$ & IL bleomycin (retrospective study) & CC (73\%), RR (23\%) & 6 months \\
\hline
\end{tabular}

RCT: randomized controlled trial, CC: clinical clearance, RR: recurrence rate.

selected difficult site warts, but they had also not received any treatment in the past [9]. However, we had chosen difficult site warts with treatment failure with at least 2 prior treatment sessions with other modalities.
Alghamdi et al. [17] treated most of the periungual warts with past treatment failure with much lesser bleomycin concentration using the multipuncture technique, with good clearance rate $(86.6 \%)$ and lesser recurrence rate $(13.33 \%)$ 
[17]. Unlike other reports, we had a higher recurrence rate (15.78\%). The possible explanation could be that we have not conducted a dermoscopic evaluation to find complete clearance. As supported by the work of Barkat et al., without dermoscopic evaluation, we may miss $19.2 \%$ of cases. In their study, $69.3 \%$ clearance was obtained with dermoscopy evaluation, but $88.5 \%$ clearance was obtained when evaluated only clinically [12]. In the work of Dhar et al., recurrence was lesser $(13 \%)$ than ours. However, they had chosen all patients without prior treatment and the follow-up duration was 4 weeks lesser than that of our study [8]. But, we had selected only recalcitrant warts with a slightly longer follow-up. Hence, we might have a higher recurrence. However, in a study that has chosen recalcitrant plantar warts, $19.35 \%$ recurrence was seen in 6 months [16]. Similarly, in a study which included difficult site recalcitrant warts, RR was $23 \%$ in 6 months (Table 2) [5].

Pain for a few initial days was the most common side effect; transient pigmentation was seen among 3 patients. However, none of them had serious adverse effects. These findings are comparable to other reports $[9,12-18]$. One previous study detected reversible necrosis in $1.2 \%$ of the patients with IL bleomycin injected for ungual warts [19]. However, we did not observe such complications.

4.1. Limitations of the Study. Retrospective case series with lesser sample size and shorter follow-up after the last intervention are the major limitations of our study.

\section{Conclusions}

In our study, there was a good number of complete clearance (89.47\%) after two sessions of IL bleomycin for the treatment of difficult sites and resistant warts. None of the participants had severe adverse effects. Therefore, IL bleomycin could be a safe, better, and promising treatment option for resistant warts in difficult sites. However, we observed a higher recurrence rate even in a shorter follow-up period (15.78\%). We need further studies, preferably randomized controlled trials with larger samples. Furthermore, we recommend including dermoscopic evaluation for the assessment of complete clearance.

\section{Data Availability}

Data will be deposited in a repository, or they can also be obtained from the corresponding author on request.

\section{Conflicts of Interest}

The authors declare no conflicts of interest.

\section{Acknowledgments}

The authors would like to express their sincere thanks to all participants of this study. Likewise, they are indebted to all faculty, residents, and staff of the Dermatology Department of B. P. Koirala Institute of Health Sciences who have helped directly as well as indirectly to carry out this study.

\section{References}

[1] S. K. Loo and W. Y. Tang, "Warts (non-genital) search date october 2013 warts (non-genital)," BMJ-Clinical Evidence, vol. 6, 2014.

[2] J. C. Sterling, S. Handfield-Jones, and P. M. Hudson, "Guidelines for the management of cutaneous warts," British Journal of Dermatology, vol. 144, no. 1, pp. 4-11, 2001.

[3] P. Saitta, K. Krishnamurthy, and L. H. Brown, "Bleomycin in dermatology: a review of intralesional applications," Dermatologic Surgery, vol. 34, no. 10, pp. 1299-1313, 2008.

[4] E. Mulhem and S. Pinelis, "Treatment of nongenital cutaneous warts," American Family Physician, vol. 84, no. 3, pp. 288-293, 2011.

[5] M.-H. Aziz-Jalali, G. Ghafarpour, M. R. Rezaei, A. Heshmatzadeh Behzadi, M. Rohani Nasab, and M. A. Nilforoushzadeh, "Efficacy of intralesional bleomycin in the treatment of resistant warts," Journal of Skin and Stem Cell, vol. 1, no. 1, Article ID e18875, 2014.

[6] C. S. Kwok, R. Holland, and S. Gibbs, "Efficacy of topical treatments for cutaneous warts: a meta-analysis and pooled analysis of randomized controlled trials," British Journal of Dermatology, vol. 165, no. 2, pp. 233-246, 2011.

[7] T. G. Lewis and E. D. Nydorf, "Intralesional bleomycin for warts: a review," Journal of Drugs in Dermatology: Journal of Drugs in Dermatology, vol. 5, no. 6, pp. 499-504, 2006, https:// pubmed.ncbi.nlm.nih.gov/16774100/.

[8] S. Dhar, M. Rashid, A. Islam, and M. Bhuiyan, "Intralesional bleomycin in the treatment of cutaneous warts: a randomized clinical trial comparing it with cryotherapy," Indian Journal of Dermatology, Venereology and Leprology, vol. 75, no. 3, pp. 262-267, 2009.

[9] P. Soni, K. Khandelwal, N. Aara, B. Ghiya, R. Mehta, and R. Bumb, "Efficacy of intralesional bleomycin in palmoplantar and periungual warts," Journal of Cutaneous and Aesthetic Surgery, vol. 4, no. 3, pp. 188-192, 2011.

[10] C. Kwok, S. Gibbs, C. Bennett, R. Holland, and R. Abbott, "Topical treatments for cutaneous warts (review)," Cochrane Database of Systematic Reviews, no. 9, Article ID CD001781, 2012.

[11] K. M. Alghamdi and H. Khurram, "Successful treatment of plantar warts with very diluted bleomycin using a translesional multipuncture technique: pilot prospective study," Journal of Cutaneous Medicine and Surgery, vol. 16, no. 4, pp. 250-256, 2012.

[12] M. T. Barkat, R. T. A. Abdel-Aziz, and M. S. Mohamed, "Evaluation of intralesional injection of bleomycin in the treatment of plantar warts: clinical and dermoscopic evaluation," International Journal of Dermatology, vol. 57, no. 12, pp. 1533-1537, 2018.

[13] P. Pasquali, A. Frietes-Martinez, S. Gonzalez, E. Spugnini, and A. Baldi, "Successful treatment of plantar warts with intralesional bleomycin and electroporation: pilot prospective study," Dermatology Practical and Conceptual, vol. 7, no. 3, pp. 21-26, 2017.

[14] H. Adalatkhah, H. Khalilollahi, N. Amini, and H. SadeghiBazargani, "Compared therapeutic efficacy between intralesional bleomycin and cryotherapy for common warts: a randomized clinical trial," Dermatology Online Journal, vol. 13, no. 3, p. 4, 2007.

[15] M. R. Al-Naggar, A. S. Al-Adl, A. R. Rabie, M. R. Abdelkhalk, and M. L. Elsaie, "Intralesional bleomycin injection vs microneedling-assisted topical bleomycin spraying in 
treatment of plantar warts," Journal of Cosmetic Dermatology, vol. 18, no. 1, pp. 124-128, 2019.

[16] R. Salk and T. S. Douglas, "Intralesional bleomycin sulfate injection for the treatment of verruca plantaris," Journal of the American Podiatric Medical Association, vol. 96, no. 3, pp. 220-225, 2006.

[17] K. M. Alghamdi and H. Khurram, "Successful treatment of periungual warts with diluted bleomycin using translesional multipuncture technique: a pilot prospective study," Dermatologic Surgery, vol. 37, no. 4, pp. 486-492, 2011.

[18] L. F. Noriega, L. d. S. Valandro, N. G. D. Chiacchio, M. L. Vieira, and N. D. Chiacchio, "Tratamento de verrugas virais com bleomicina intralesional," Surgical \& Cosmetic Dermatology, vol. 10, no. 1, pp. 17-21, 2018.

[19] A. Singal and C. Grover, "Efficacy and safety of intralesional bleomycin in the management of ungual warts," Skin Appendage Disorders, vol. 6, no. 6, pp. 346-350, 2020. 